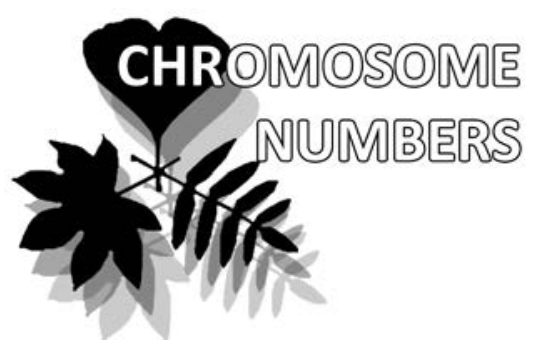

\title{
A new record of chromosome count in mixoploid karyotype of Strobilanthes hamiltoniana (Steud.) Bosser \& Heine (Acanthaceae)
}

\author{
Reshmi Chembrammal* \& John Ernest Thoppil
}

Reshmi Chembrammal ${ }^{1 *}$

e-mail: reshmibalan824@gmail.com

John Ernest Thoppil

e-mail: jethoppil@gmail.com

Cell and Molecular Biology Division, Department of Botany, University of Calicut, Kerala, India

* corresponding author

Manuscript received: 27.12.2021

Review completed: 05.02.2022

Accepted for publication: 17.02 .2022

Published online: 20.02.2022

\begin{abstract}
A B S T R A C T
The mixoploid karyotype found in the garden plant, Strobilanthes hamiltoniana, is a new record of chromosome count to the contemporary knowledge. The detailed karyomorphometrical analysis of the plant revealed a symmetric karyotype which is primitive. A hypoploid variant along with the normal chromosome complement was recorded within a root meristem with karyotype formulae as $10 \mathrm{~nm}$ and $20 \mathrm{~nm}$ respectively. In the diploid cells two pair of chromosomes have secondary constriction with an average chromosome length of $1.81 \mu \mathrm{m}$. The high values of symmetric indices and low values of asymmetric indices proved the primitive nature of the karyotype.
\end{abstract}

Keywords: mixoploidy, Strobilanthes hamiltoniana, karyotype, symmetric, polysomaty

\begin{abstract}
P E 3 Ю M E
Чембраммах Р., Топпил Аж.Э. Новое число хромосом в миксоплоиАном кариотипе Strobilanthes hamiltoniana (Steud.) Bosser \& Heine (Acanthaceae). Миксоплоилный кариотип, обнаруженный у садового растения Strobilanthes hamiltonian, - это новое число хромосом Аля Аанного виАа. Аетальный кариоморфометрический анализ растения позволиц выявить симметричный кариотип, что яв яется примитивным признаком. Гипоплоидный вариант наряду с нормальным дополнением хромосом был зарегистрирован в корневой меристеме с формулами кариотипа 10 нм и 20 нм, соответственно. В Аиплоидных клетках Аве пары хромосом имеют вторичное сужение со средней Алиной хромосомы 1,81 мкм. Высокие значения симметричных индексов и низкие значения асимметричных индексов подтвержАают примитивный характер кариотипа.
\end{abstract}

КАючевые слова: миксоплоидия, Strobilanthes hamiltoniana, кариотип, симметричность, полисоматичность

(10) $-$ 


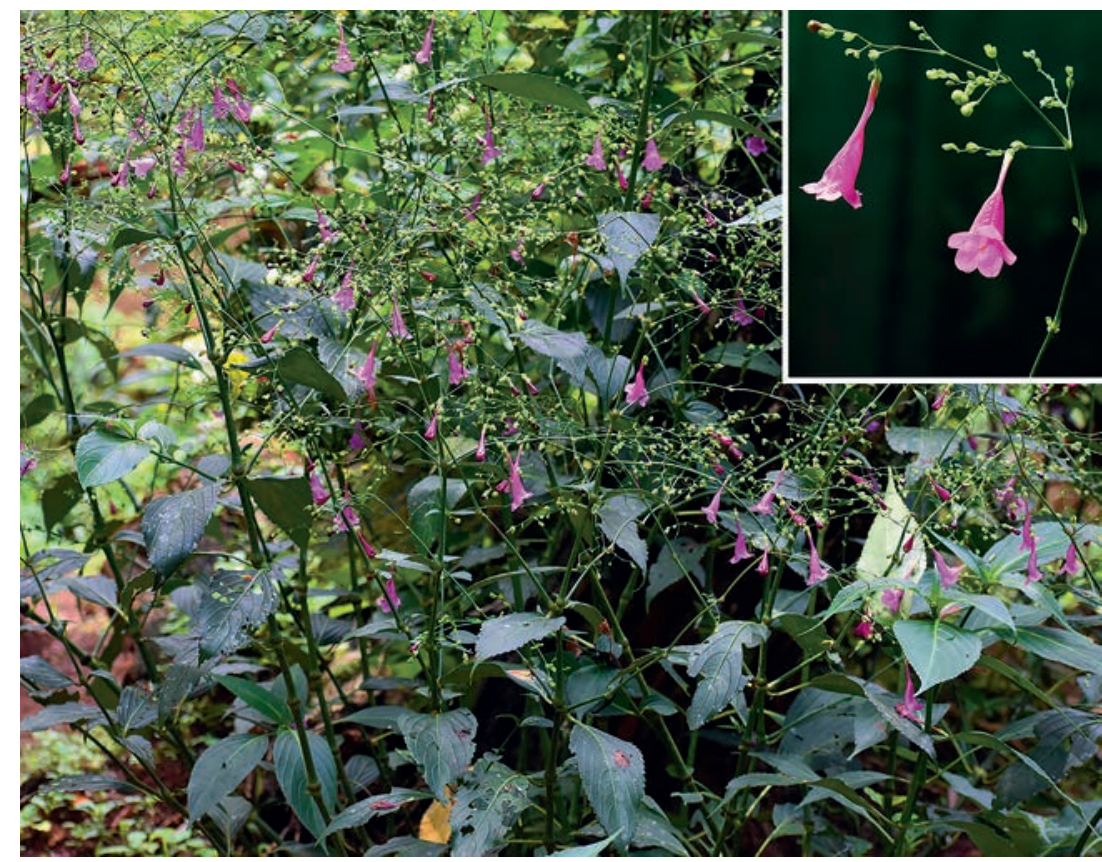

Figure 1 Habit of Strobilanthes hamiltoniana (Steud.) Bosser \& Heine. Inset: enlarged view of inflorescence

meters were calculated and tabulated to analyse the symmetry of karyotype. The karyograms and idiograms were also drawn (Fig. 3).

The cytogenetical characterisation of $S$. hamiltoniana revealed a mixoploid karyotype. Mixoploidy or polysomaty is the presence of diploid and polyploid cells within a root meristem in which dominating cell fraction will be diploid (Chembrammal \& Thoppil 2021). The somatic chromosome in this study was found to be $2 \mathrm{n}=20$ with a base number as $\mathrm{x}=10$. In diploid as well as variant cells all the chromosomes were nearly median with karyotype formulae as $20 \mathrm{~nm}$ and $10 \mathrm{~nm}$ respectively. The presence of median/nearly median chromosomes signifies the primitiveness and the terminal centromeres represent the advanced ones (Imai et al. 2001). So, the species under investigation point out the primitive nature of the karyotype. The previous reports of the genus also convey the centromere position in the genus

classified according to Abraham \& Prasad (1983). With the help softwares paired chromosomes were subjected to karyogram preparation.

The data represented throughout the work were subjected to statistical analysis using IBM SPSS Statistics Version 20. The data obtained were analyzed in One-Way ANOVA followed by the Duncans Multiple Range Test (DMRT) to confirm the variability of data and validity of results. All the values were expressed in mean \pm standard error. The statistical significance was determined with $\mathrm{p}<0.05$, which is considered significant.

\section{RESULTS AND DISCUSSION}

The annually flowering garden plant $S$. hamiltoniana have shown two different karyotypes (Fig. 2). The two different chromosome counts such as $2 \mathrm{n}=10,20$ with karyotype formulae as $10 \mathrm{~nm}$ and $20 \mathrm{~nm}$ respectively (Tables 1,2). The species has nearly median chromosome pairs in both hypoploid and somatic cells. The chromosome length was 9.88 and $18.07 \mu \mathrm{m}$ in cell with $2 \mathrm{n}=10$ and 20 respectively. In somatic chromosome, 2 pair of chromosomes were having secondary constrictions with an average chromosome length of $1.81 \mu \mathrm{m}$ (Table 3). The karyomorphometric paraas mainly median to sub-median with a few having subterminal ones (Govindarajan \& Subramanian 1983, 1985).

According to Vimala et al. (2021) karyotype description includes chromosome number, genome size, the absolute and relative size of a chromosome, centromere position leading to the symmetry of chromosome, number and position of secondary constriction/satellite and heterochromatin distribution. Chromosome number is an important parameter as it gives substantial information about a species (Anil et al. 2013). The value of the range of chromosomes of this species stands within the limits of the Strobilanthes which was given as 4.5-0.8 $\mu \mathrm{m}$ (Chembrammal \& Thoppil 2021). The total chromosome length in diploid and hypoploid cells of $S$. hamiltoniana does not accompany exact duplication. Hence, it cannot be called true polyploidy. The changes in the number and structure of chromosomes are being linked to the evolution and speciation of plants (Astuti et al. 2017). The number of chromosomes with secondary constriction was 2 and 4 in variant and normal cytotype. The position of the centromere is the landmark of the chromosome while considering the chromosome morphology.

Karyotypic analysis has been successfully employed to estimate the intraspecific and interspecific levels of taxo-

Table 1. Detailed karyomorphometric data of $S$. hamiltoniana somatic variant cytotype with 10 chromosomes, all nearly medium. * - chromosome with secondary constriction, values are expressed in Mean \pm SE.

\begin{tabular}{|c|c|c|c|c|c|c|c|}
\hline $\begin{array}{l}\text { Number of } \\
\text { chromosome } \\
\text { pairs }\end{array}$ & $\begin{array}{l}\text { Total length of } \\
\text { chromosome } \\
(\mu \mathrm{m})\end{array}$ & $\begin{array}{l}\text { Short arm } \\
\text { length }(\mu \mathrm{m})\end{array}$ & $\begin{array}{l}\text { Long arm } \\
\text { length }(\mu \mathrm{m})\end{array}$ & $\begin{array}{l}\text { Arm ratio } 1, R_{1} \\
(\mathrm{~s} / 1)\end{array}$ & $\begin{array}{l}\text { Arm ratio } 2, R_{2} \\
(1 / s)\end{array}$ & $\begin{array}{l}\text { Centromeric } \\
\text { index } 1, I_{1} \\
\left(\mathrm{~s} / \mathrm{c}^{0} \%\right)\end{array}$ & $\begin{array}{l}\text { Centromeric } \\
\text { index } 2 I_{2} \\
(1 / c \%)\end{array}$ \\
\hline $2 *$ & $2.80 \pm 0.44$ & $1.15 \pm 0.16$ & $1.55 \pm 0.09$ & $0.77 \pm 0.04$ & $1.40 \pm 0.23$ & $42.63 \pm 4.41$ & $57.37 \pm 4.42$ \\
\hline 2 & $2.20 \pm 0.30$ & $1.05 \pm 0.16$ & $1.16 \pm 0.14$ & $0.90 \pm 0.01$ & $1.12 \pm 0.06$ & $47.19 \pm 1.28$ & $57.81 \pm 1.28$ \\
\hline 2 & $1.83 \pm 0.44$ & $0.89 \pm 0.23$ & $0.76 \pm 0.09$ & $0.94 \pm 0.09$ & $1.07 \pm 0.02$ & $48.34 \pm 0.28$ & $51.66 \pm 0.28$ \\
\hline 2 & $1.63 \pm 0.25$ & $0.75 \pm 0.14$ & $1.03 \pm 0.18$ & $0.86 \pm 0.09$ & $1.19 \pm 0.14$ & $45.92 \pm 2.70$ & $54.08 \pm 2.70$ \\
\hline 2 & $1.42 \pm 0.17$ & $0.66 \pm 0.08$ & $0.88 \pm 0.13$ & $0.87 \pm 0.05$ & $1.17 \pm 0.12$ & $46.29 \pm 2.52$ & $53.71 \pm 2.52$ \\
\hline
\end{tabular}




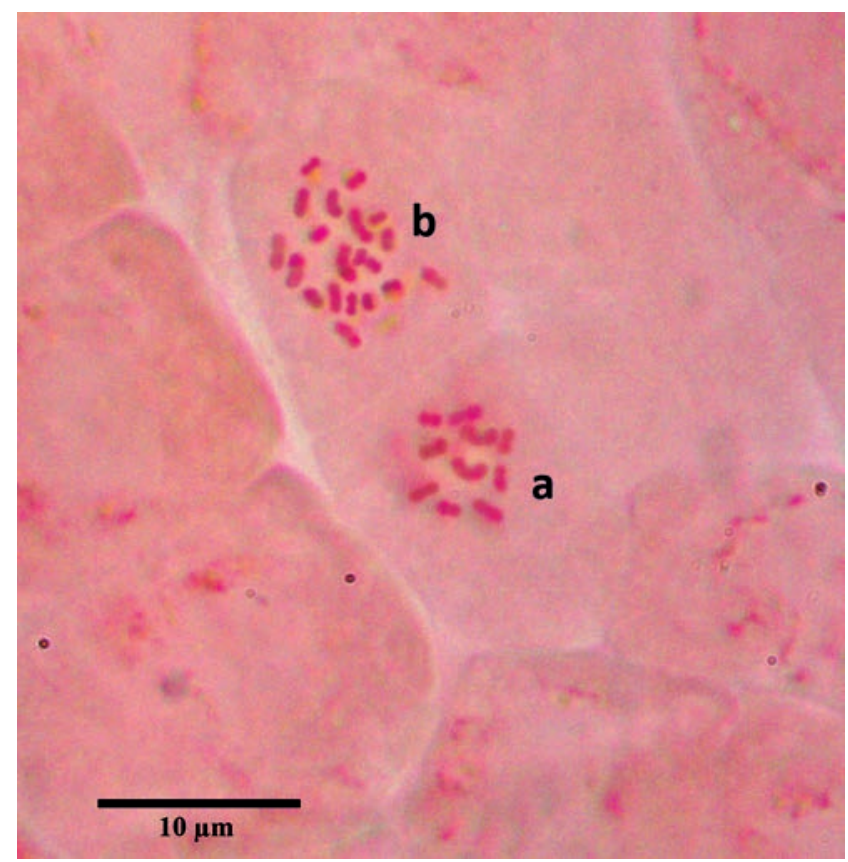

Figure 2. Somatic metaphase chromosome complements of Strobilanthes hamiltoniana; A - variant cytotype with 10 chromosomes; $\mathrm{b}$ - normal diploid with $2 \mathrm{n}=20$ chromosomes

nomic relationships between species (Beevy \& Bai 2013). A combination of parameters was analysed to conclude the symmetry of the species. The dispersion index (DI) is used to differentiate closely related karyotype asymmetry in evolutionary order, easing the development of species (Vimala et al. 2021). This proportionate measure of the centromeric gradient to the coefficient of variation for chromosome length was very low in $S$. hamiltoniana indicating the poorly specialized karyotype (Lavania \& Srivastava 1992). It has importance in arranging the species within the same class of karyotype asymmetry by permitting further gradations, as depicted by species rearrangements within sections ( $\mathrm{Ha}-$ mideh et al. 2009). Total forma percentage ( $\mathrm{TF} \%)$ is widely used to evaluate the karyotype symmetry/asymmetry and the karyotypic relationship between species (Costa \& Forni-Martins 2003). The highest TF\% value in this plant is following with the previous reports suggesting the possible

\section{1)

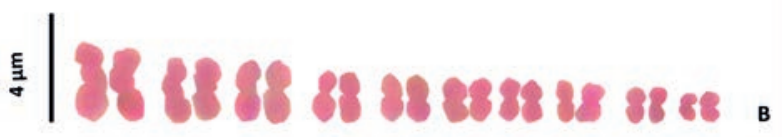

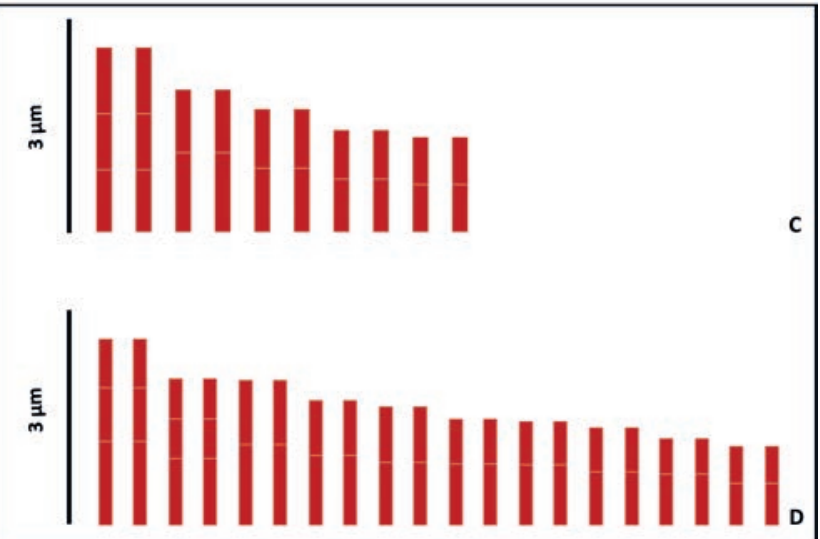

Figure 2. Mitotic chromosome complement images of Strobilanthes hamiltoniana. A - karyograms of variant cytotype with 10 chromosomes; B - karyograms of normal cytotype with $2 \mathrm{n}=20, \mathrm{C}-\mathrm{D}-$ respective idiograms

symmetric karyotype of the species (Biswas \& Mukhopadhyay 2020).

The two indices developed by Greilhuber \& Speta (1976) and later called by Venora were Syi and Rec indices. The higher value of Rec index, Syi index and lower values of Karyotype ksymmetry index (As $\mathrm{K} \%$ ) extent the symmetry of karyotype and decreases the probability for asymmetry (Saha et al. 2021, Prajitha \& Thoppil 2018). In respect to centromere position karyotype, symmetry can be studied using As $\mathrm{K} \%$, intrachromosomal asymmetry index (A1), interchromosomal asymmetry index (A2) and degree of asymmetry of karyotypes (A) indices. The high symmetric and more primitive karyotype is depicted by the closer $50 \%$ value of As K\% (Ye et al. 2014). Accordingly in this investigation, the species has recorded 54.45 and $55.29 \%$ for hypoploid and diploid complements respectively. When the centromere shifts from median/submedian to terminal/

Table 2. Detailed karyomorphometric data of $S$. hamiltoniana normal cytotype with 20 chromosomes, all nearly medium. ${ }^{*}-$ chromosome with secondary constriction, values are expressed in Mean \pm SE.

\begin{tabular}{|c|c|c|c|c|c|c|c|}
\hline $\begin{array}{l}\text { Number of } \\
\text { chromosome } \\
\text { pairs }\end{array}$ & $\begin{array}{l}\text { Total length of } \\
\text { chromosome } \\
(\mu \mathrm{m})\end{array}$ & $\begin{array}{l}\text { Short arm } \\
\text { length }(\mu \mathrm{m})\end{array}$ & $\begin{array}{l}\text { Long arm } \\
\text { length }(\mu \mathrm{m})\end{array}$ & $\begin{array}{l}\text { Arm ratio } 1, R_{1} \\
(s / 1)\end{array}$ & $\underset{(1 / s)}{\operatorname{Arm}}$ ratio $2, R_{2}$ & $\begin{array}{l}\text { Centromeric } \\
\text { index } 1, I_{1} \\
(\mathrm{~s} / \mathrm{c} \%)\end{array}$ & $\begin{array}{l}\text { Centromeric } \\
\text { index } 2 I_{2} \\
(1 / \mathrm{c} \%)\end{array}$ \\
\hline $2^{*}$ & $2.78 \pm 0.42$ & $1.25 \pm 0.22$ & $1.53 \pm 0.20$ & $0.81 \pm 0.05$ & $1.25 \pm 0.07$ & $44.60 \pm 1.45$ & $55.39 \pm 1.45$ \\
\hline $2^{*}$ & $2.26 \pm 0.37$ & $0.99 \pm 0.15$ & $1.27 \pm 0.23$ & $0.79 \pm 0.03$ & $1.27 \pm 0.05$ & $44.00 \pm 1.03$ & $55.94 \pm 1.03$ \\
\hline 2 & $2.07 \pm 0.16$ & $0.97 \pm 0.11$ & $1.20 \pm 0.06$ & $0.88 \pm 0.06$ & $1.14 \pm 0.07$ & $46.70 \pm 1.68$ & $53.26 \pm 1.68$ \\
\hline 2 & $1.87 \pm 0.18$ & $0.83 \pm 0.04$ & $1.04 \pm 0.14$ & $0.83 \pm 0.08$ & $1.24 \pm 0.12$ & $44.96 \pm 2.58$ & $55.04 \pm 2.58$ \\
\hline 2 & $1.77 \pm 0.19$ & $0.83 \pm 0.07$ & $0.94 \pm 0.12$ & $0.89 \pm 0.05$ & $1.12 \pm 0.06$ & $47.17 \pm 1.45$ & $52.82 \pm 1.45$ \\
\hline 2 & $1.63 \pm 0.20$ & $0.67 \pm 0.11$ & $0.92 \pm 0.15$ & $0.75 \pm 0.08$ & $1.36 \pm 0.14$ & $42.61 \pm 2.51$ & $57.39 \pm 2.51$ \\
\hline 2 & $1.54 \pm 0.22$ & $0.65 \pm 0.08$ & $0.90 \pm 0.13$ & $0.76 \pm 0.05$ & $1.34 \pm 0.09$ & $42.94 \pm 1.76$ & $57.06 \pm 1.76$ \\
\hline 2 & $1.47 \pm 0.22$ & $0.66 \pm 0.09$ & $0.80 \pm 0.14$ & $0.84 \pm 0.05$ & $1.19 \pm 0.07$ & $45.77 \pm 1.41$ & $54.22 \pm 1.41$ \\
\hline 2 & $1.50 \pm 0.05$ & $0.54 \pm 0.08$ & $0.76 \pm 0.09$ & $1.04 \pm 0.33$ & $1.15 \pm 0.32$ & $48.74 \pm 7.56$ & $51.26 \pm 7.56$ \\
\hline 2 & $1.18 \pm 0.16$ & $0.55 \pm 0.08$ & $0.63 \pm 0.08$ & $0.87 \pm 0.03$ & $1.15 \pm 0.04$ & $46.50 \pm 0.91$ & $53.50 \pm 0.91$ \\
\hline
\end{tabular}


Table 3. Summary of karyomorphometrical data of different cytotypes of S. hamiltoniana.

\begin{tabular}{lll}
\hline Cromosome characterictics & \multicolumn{2}{l}{ Somatic chromosome number } \\
\cline { 2 - 3 } & $\mathbf{1 0}$ & $\mathbf{2 0}$ \\
\hline Karyotype formula & $10 \mathrm{~nm}$ & $20 \mathrm{~nm}$ \\
Number of chromosomes with secondary constriction & 2 & 4 \\
Range of chromosome length (RCL) & $2.8-1.42 \mu \mathrm{m}$ & $2.78-1.18 \mu \mathrm{m}$ \\
Total chromosome length (TCL) & $9.88 \mu \mathrm{m}$ & $18.07 \mu \mathrm{m}$ \\
Average chromosome length (ACL) & $1.98 \mu \mathrm{m}$ & $1.81 \mu \mathrm{m}$ \\
Dispersion index (DI) & 12.35 & 15.82 \\
Total forma percentage (\%) & 45.54 & 43.94 \\
Karyotype asymmetry index (As K\%) & 54.45 & 55.29 \\
Syi index & 84.29 & 79.07 \\
Rec index & 70.57 & 65 \\
Intrachromosomal asymmetry index (A1) & 0.14 & 0.21 \\
Interchromosomal asymmetry index (A2) & 0.26 & 0.27 \\
Degree of asymmetry of karyotypes (A) & 0.08 & 0.12 \\
\hline
\end{tabular}

the assessed parameters the species seems to be more symmetric with equal-armed chromosomes. As the centromere shifts the asymmetry increases. The mixoploid condition might have arise to overcome the bottle neck effect of the environment. The findings are an addition to the chromosome data base for further tracking of the phylogenetic relationships of the genus.

\section{ACKNOWLEDGEMENTS}

The authors are thankful for the taxonomic identification of the plant specimen by senior scientist Dr. K.M. Prabhukumar, Plant Diversity,

subterminal the intrachromosomal asymmetry increases. According to Romero-Zarco (1986) the intermediate value for A1 ranges between $0.18-0.22$. The $A 1$ and $A$ values increase with an increase in asymmetry (Zuo \& Yuan 2011). So, the minor values of $\mathrm{A} 1$ and $\mathrm{A}$ is due to the decreasing asymmetry leading to symmetric karyotype.

Polyploid mixoploidy is the most common mixoploidy seen in Angiosperms (Ranjbar et al. 2011). In other words, mixoploidy or the intra-individual variation in chromosome number is the presence of more than one chromosome number in a cellular population (Pierre et al. 2011). It is reported in in vitro propagation, in which the major report was in anther culture (Xin-Hua et al. 2010). Their presence is mostly reported in genera having small-sized chromosomes (Truta et al. 2011), in Strobilanthes it was first repoted in the species $S$. virendrakumarana (Chembrammal \& Thoppil 2021). The average chromosome size in this species was found to be 1.98 and $1.81 \mu \mathrm{m}$ in variant and normal cytotypes respectively reveals the small size of the chromosome. The adaptivity of a plant can be enhanced by a high level of mixoploidy which lead to genome plasticity (Kunakh et al. 2008).

By increasing the chromosome number by fragmentation, greater variability and adaptability will be acquired (Mola \& Papeschi 2006). When plants are exposed to abiotic stresses karyotypes tend to evolve to polyploidy which is suitable for the environment (Mayrose et al. 2010). It is believed that polysomaty arises from diploid meristems on a particular stage of ontogenesis. It is most common in plants with vegetative and apomictic propagation (Kunakh 1995). The instability in cell genome within a meristem can induce ability for hybridisation and polyploidisation. These in turn can lead to epigenetic and epigenomic rearrangements (Kunakh et al. 2008). The interpretation of the evolution of a karyotype is based on chromosomal structural constraints and the degree to which persistent epigenetic chromatin alterations exist in a species (Vimala et al. 2021).

\section{CONCLUSION}

Chromosome studies of $S$. hamiltoniana revealed $2 \mathrm{n}=$ 20 with a base set of 10 chromosomes. The results point out the symmetric karyotype of the plant in the somatic variant as well as normal cytotype. While correlating all
Systematics and Herbarium, CSIR-NBRI, Lucknow and Dr. A.K. Pradeep, Associate Professor, Department of Botany, University of Calicut. The first author's gratitude towards Dr. Maya C. Nair, Assistant Professor, Department of Botany, Govt. Victoria College and Ms. Ramya Sree PR during the specimen collection are greatly mentioned. The first author was financially supported by Council of Scientific and Industrial Research (CSIR) in the form of senior research fellowship (09/043(0186)/2017-EMR-1).

\section{LITERATURE CITED}

Abraham, Z. \& P.N. Prasad 1983. A system of chromosome classification and nomenclature. Cytologia 48(1):95-101.

Anil, S.R. \& E.A. Siril 2015. Karyosystematic studies in Amorphophallus Blume ex Decne. Journal of Root Crops 39(2):39-50.

Astuti, G., F. Roma-Marzio \& L. Peruzzi 2017. Traditional karyomorphological studies: can they still provide a solid basis in plant systematics. Flora Mediterranea 27:91-98.

Augustine J. 2018. Strobilanthes in the Western ghats, India. Malabar Natural History Society, Kozhikode, 94 pp.

Beevy, S.S. \& N.H. Bai 2013. Karyotypic analysis of parents and F 1 hybrids of intra-specific crosses in Momordica charantia L. The Nucleus 56(2):99-105.

Biswas, T. \& S. Mukhopadhyay 2020. Comparison of different cytological parameters of three species of Ocimum. Bangladesh Journal of Botany 49(4):1163-1167.

Chembrammal, R. \& J.E. Thoppil 2021. Mixoploidy in Strobilanthes anamallaica J.R.I. Wood (Acanthaceae Juss.) an important taxon of south-western Ghat, India. The Nucleus 2021:1-6.

Costa, J.Y. \& E.R. Forni-Martins 2003. Karyology of some Brazilian species of Alismataceae. Botanical Journal of the Linnean Society 143(2):159-164.

Gouas, L., C. Goumy, L. Véronèse, A. Tchirkov \& P. Vago 2008. Gene dosage methods as diagnostic tools for the identification of chromosome abnormalities. Pathologie Biologie 56(6):345-353.

Govindarajan, T. \& D. Subramanian 1983. Karyomorphological studies in south Indian Acanthaceae. Cytologia 48(3): 491-504.

Govindarajan, T. \& D. Subramanian 1985. Karyomorphological studies in south Indian Acanthaceae. Cytologia 50(3): 473-482. 
Greilhuber, J. \& F. Speta 1976. C-banded karyotypes in the Scilla bohenackeri group, S. persica and Puschkinia (Liliaceae). Plant Systematics and Evolution 126(2):149-188.

Hamideh, J., S.M. Hesamzadeh Hejazi \& M.S. Babayev 2009. Karyotypic studies of three Thymus (Lamiaceae) species and populations in Iran. Caryologia 62(4):316-325.

Imai, H.T., Y. Satta \& N. Takahata 2001. Integrative study on chromosome evolution of mammals, ants and wasps based on the minimum interaction theory. Journal of Theoretical Biology 210(4):475-497.

Kunakh, V.A. 1995. Genomic variability of somatic plant cells. 2. Variability in nature. Biopolimery $i$ Kletka 11(6):5-40 (in Russian). [Кунах B.A. 1995. Геномная изменчивость соматических клеток растений // Биополимеры и клетка. Т. 11, № 6. С. 5-40].

Kunakh, V.A., V.I. Adonin, S.P. Ozheredov \& Ya.B. Blyum 2008. Mixoploidy in wild and cultivated species of Cruciferae capable of hybridizing with rapeseed Brassica napus. Tsitologiya i Genetica 42(3):204-209 (in Ukrainian). [Kyнах В.А, ААонін В.І., Ожередов С.П., БАюм Я.Б. 2008. МіксоплоїАія у диких та культивованих видів хрестосвітих, зАатних до гібридизації з ріпаком Brassica napus // Цитология и генетика. Т. 42, № 3. С. 204-209].

Lavania, U. C. \& S. Srivastava 1992. A simple parameter of dispersion index that serves as a adjunct to karyotype asymmetry. Journal of Bioscience 17:179-182.

Mayrose, I., M.S. Barker \& S.P. Otto 2010. Probabilistic models of chromosome number evolution and the inference of polyploidy. Systematic Biology 59:132-144.

Mola, L.M. \& A.G. Papeschi 2006. Holokinetic chromosomes at a glance. Journal of Basic and Applied Genetics 17(1):17-33.

Montazerinezhad, S., A. Emamjomeh \& B. Hajieghrari 2020. Chromosomal abnormality, laboratory techniques, tools and databases in molecular cytogenetics. Molecular Biology Reports 47:9055-9073.
Pierre, P.M., S.M. Sousa, L.C. Davide, M.A. Machado \& L.F. Viccini 2011. Karyotype analysis, DNA content and molecular screening in Lippia alba (Verbenaceae). Anais da Academia Brasileira de Ciências 83:993-1006.

Prajitha, V.\&J.E. Thoppil. 2018. Cytogenetic characterization of Amaranthus caudatus L. and Amaranthus bybridus subsp. cruentus (L.) Thell. Cytotechnology 70(1):95-101.

Ranjbar, M., R. Karamian \& S. Nouri 2011. Diploid-tetraploid mixoploidy in a new species of Astragalus (Fabaceae) from Iran. Annales Botanici Fennici 48(4):343-351.

Romero-Zarco, C. 1986. A new method for estimating karyotype asymmetry. Taxon 35:526-530.

Saha, S., F. Akbar \& K.N. Begum 2021. A report of karyotype and B-chromosome in Costus spicatus (Jacq.) Sw. from Bangladesh. Cytologia 86(1):41-45.

Sharma, A.K. \& A. Sharma 1990. Chromosome Techniques: Theory and Practice. Aditya Books, New Delhi.

Truta, E., G. Vochita, C.M. Rosu, C. Manzu, G. Gheorghita \& I.V. Rati 2011. Karyotype traits in Rosa nitidula Besser. Journal of Experimental and Molecular Biology 12(4):111-116.

Vimala, Y., S. Lavania \& U.C. Lavania 2021. Chromosome change and karyotype differentiation-implications in speciation and plant systematics. The Nucleus 64:33-54.

Xin-Hua, Z., J.A. T.D. Silva \& G.H. Ma 2010. Karyotype analysis of Santalum album L. Caryologia 63(2):142-148.

Ye, J.Q., Y.Y. Jia, K. Fan, X.J. Sun \& X.M. Wang 2014. Karyotype analysis of Rheum palmatum. Genetics and Molecular Research 13(4):9056-9061.

Zuo, L. \& Q. Yuan 2011. The difference between the heterogeneity of the centromeric index and intrachromosomal asymmetry. Plant Systematics and Evolution 297(1):141-145. 